Received: 01.12.2012; Final Text: 02.11.2014

Keywords: Analytic Hierarchy Process (AHP); architectural design quality; Multi Criteria Decision Making (MCDM).

1. This article is mainly based on the dissertation of Harputlugil (2012).
* Department of Architecture, Çankaya University, Ankara, TURKEY.

** Department of Architecture, Atılım University, Ankara, TURKEY.

*** Department of Real Estate \& Housing Technische Universiteit Delft, Delft, THE NETHERLANDS.

**** Department of Industrial Engineering, İstanbul Technical University, İstanbul, TURKEY.

\section{ARCHITECTURAL DESIGN QUALITY ASSESSMENT BASED ON ANALYTIC HIERARCHY PROCESS: A CASE STUDY (1)}

\author{
Timuçin HARPUTLUGIL* , A.Tanju GÜLTEKİN**, \\ Matthijs PRINS ${ }^{* * *}$, Y. İlker TOPÇU****
}

\title{
INTRODUCTION
}

"As complexity and scale of design processes in architecture and in engineering increase, as well as the demands on these processes with respect to costs, throughput time and quality, traditional approaches to organise and plan these processes may no longer suffice (Van Aken, 2003)"

Architectural design is an iterative process, having numerous parameters that are constantly evaluated through feedback. Each architectural design can most often be seen as a one-off production. There are several approaches to defining architectural design in the literature. According to Chan (1990), architectural design is a kind of problem solving based on actions in order to solve a design problem. Simon (1969) identifies design as an ill-defined process since it creates its own problems, while Lawson (2005) characterises design problems under three main items as follows: 1 ) Design problems cannot be comprehensively stated, 2) Design problems require subjective interpretation, and 3) Design problems tend to be organised hierarchically.

The design process is complex due to its content, context, stakeholders, ill-defined problems, and moreover their multifaceted interactions. Furthermore each design process has special characteristics which are not easily standardised. Gann et al. (2003) stated the difficulty of quantifying the quality of architectural design since it consists of both tangible and intangible facts and objective-subjective components.

Although there are several tools developed for design quality assessment, they are limited due to their focus on the usage phase (mostly used for the occupancy period), their assessment methodology (mostly to cope with evaluation of intangible criteria), their mathematical calculations, their inability to measure the consistency of data gathered from inexperienced participants, and finally their lack of coverage of the ideas of all stakeholders. All these and the predominance of data collected in the 
occupancy period makes it impossible to transfer design knowledge for the building assessed.

Based on the problems of the current tools, this article introduces an Analytic Hierarchy Process (AHP) based approach which aims to assess architectural design quality within the design process from the perspectives of stakeholders' preferences, departing from a conception of architectural design quality which is in the eye of the beholder. This article considers the term "quality" in architectural design as the weighted sum of qualitative and quantitative preferences of the stakeholders. The goal of the approach is to collect and to categorise various decision perspectives of each stakeholder for better decision making and forecasting, aiming to improve architectural design quality. The approach is intended to be used for the full range of design processes, starting from pre-design to final design. Quality assessments from multiple stakeholders might also be useful in terms of providing designers with inputs for improving their design based on stakeholder preferences. In addition, the AHP-based approach, as developed and described within this study, is beneficial for making decisions at design team meetings at stage boundaries, for selecting between different design alternatives in case of disputes or design contests, and even for post-occupancy evaluations. The AHP-based approach might be the most useful in situations in which a large variety of stakeholders have decisive power, as is the case, for instance, in the Health Care sector. For that reason a case study has been carried out in cooperation with one of the biggest private health care providers of Turkey.

Respectively, the article defines architectural design processes and the term quality in architectural design, introduces the APH-based approach and its methodology, and discusses the applicability of the approach given the outcomes of the case study. In the conclusion, the positive and negative aspects of the approach will be reflected. The novelty of the approach is its attempt to focus on transferring stakeholders' preferences to design teams during the architectural design stages to improve architectural design quality.

\section{PROBLEM DEFINITION}

Dickson $(2004,185)$ defines the overall design and procurement process as "a series of decisions that lead progressively towards the built reality". Analysing the design process as the sum of decisions made by all the stakeholders who have decisive power throughout the design process is not the most often used way of approaching design (quality) within the framework of architecture. However, considering design as an effective decision-making process opens the possibility of applying Multi Criteria Decision Making (MCDM) techniques to assess design quality. Özcan et al. (2011) define MCDM as; "the evaluation of the alternatives for the purpose of selection or ranking, based on qualitative and/or quantitative criteria that have different measurement units" (Özcan et al. 2011, 9773).

It is widely accepted that the impacts of decisions taken in early design stages can have a significant role in ensuring the quality of the endproduct. On the other hand, most of the information necessary for assessment is acquired at the later stages of the design process. It is obvious that during these early stages, information on design quality is important to expanding the capabilities of the design team to make well-informed choices. The challenging aspect of this situation is finding ways to test and 
evaluate a design in order to control its architectural design quality from the beginning of the process, when very limited information for testing is accessible (Harputlugil et al. 2011).

Volker (2010) believes that tools developed to obtain data on architectural design quality are mostly used for post occupancy evaluation (POE) and they are limited in terms of their contribution to the design stages. POE seeks to learn how a building performs (Vischer, 2001; Dahl, 2008). Moreover, the level of users' satisfaction with the built environment is essential information for POE, which is derived from the idea that better living space could be designed by having better information provided by the users. (Vischer, 2001; Dahl, 2008).

Volker (2010) stresses that the main objective of POE is systematic evaluation of occupant satisfaction to provide an empirical basis for quality improvement, however there are still substantial limitations related to the aesthetic or overall architectural quality of a building. What is more, the data gathered from POE for architectural design quality can only be used for forthcoming designs. While this can be useful experience and guidance for designers working on future design implementations, it does not assist the design that is being assessed, except in the case of renovation.

The Design Quality Indicator (DQI) is one of the most well-known contemporary tools related to design quality assessment, amongst others such as Housing Quality Indicator (HQI), Post-Occupancy Review of Buildings and their Engineering (PROBE), Leadership in Energy and Environmental Design (LEED), Building Research Establishment Environmental Assessment Method (BREEAM), Building Quality Assessment(BQA), and the like, which evaluate the design and construction of new buildings and the refurbishment of existing buildings (Giddings, et al., 2010; DQI, 2009). DQI can be used not only for POE but also in design stages. In the evaluation process of DQI, the respondents are asked to assign a weighting to the importance of each feature on a scale of 'strongly disagree' to 'strongly agree', a process known as "Likert Scaling" (Giddings et al. 2010). Giddings et al. (2010) state the three limitations of DQI: 1) no knowledge is provided to the design process for development, 2) there is a lack of significance of hierarchy considering the quality assessment, and finally, 3) its weighting system -which is based on Likert Scaling-for evaluation. Cardellino et al. (2009) define DQI as an architecturally biased approach, which they believe underestimates the value of intangible aspects of design, and issue a warning that the tool may become a 'tick the box' exercise. Although DQI is one of the frontrunners of the current tools for assessment, as listed above, it still has limitations. Even if current tools are accepted as MCDM in some ways, using Likert Scaling is still problematic in getting data for assessment of the quality (Harputlugil et al., 2011). There is no quality assessment tool in the literature so far that is widely used and broadly accepted which uses pair-wise comparison. To cope with these and to go beyond them, scrutinising MCDM methods using pair-wise comparisons seems worthwhile as these can cope with the limitations of the current tools more easily than rated scaling techniques. The possible advantages of pair-wise comparison as included in MCDM methodologies compared to Likert Scaling techniques are discussed below.

The main objective of this research is to reveal a possible assessment approach to evaluate architectural design quality for improvement within the design process using AHP, a MCDM methodology based on comparative/pair-wise scaling techniques. Using comparative/pair-wise 
scaling rather than Likert Scaling will not only put forward the importance of criteria, but also their relative importance to each other, thereby substantially enriching the quality assessment outcomes.

\section{Objective of the Research}

Reflecting the ideas of stakeholders with decisive power in the design process might be considered a major achievement for integration. Tools for design quality assessment should take into account the accurate transference of stakeholders' ideas into the design process. There are some methodologies developed for assessment, with varying scales and methods. Rather than using Likert Scaling, which not only fails to quantify intangible aspects but also comprises heterogeneous data which cannot be transferred effectively to design input for design teams, pair-wise comparisons might be used instead to provide a relative importance of criteria, especially also when non-quantitative intangible aspects are considered. MCDM methodologies, using pair-wise comparisons, can provide consistent results for assessment. Using pair-wise comparisons for assessment may bring out the relative importance of the criteria of preferences of stakeholders. It would also allow assigning weighting factors for decision makers if necessary and/or requested.

The underlying factors in using pair-wise comparison rather than Likert Scaling can be endorsed by Saaty's $(2008,255)$ notifications as follows:

"Long before measurement scales were invented, people had no direct way to measure because they had no scales and had to compare things with each other or against a standard to determine their relative order. People still have that ability, and it is still critically necessary to be able to make comparisons much of the time, especially when they cannot measure things. ... Ancient people used their judgment to order things. The way they did it was to compare two things at a time to determine which was the larger or more preferred. By repeating the process, they obtained a total ordering of the objects without assigning them numerical values. After being ordered they could rank them: first, second, and so on" (Saaty, 2008).

\section{Definition of Quality}
"Quality is like politics, or sex, or religion. It is something everyone understands, and is convinced that he does correctly. Few would like to explain it, and discussions on it are generally short and superficial, with one or other of the participants soon changing the subject through boredom or embarrassment. We all think we understand the subject, and are all convinced that our ways are right." (Cornick, 1991, 13)

Literature has been reviewed for a common understanding of quality to reach a consensus for the rest of the research. The term "quality" is used in various contexts, but always in connection with the evaluation of a product or process (Hubka, 1992). In other words, quality can be defined both in terms of "quality is" or "quality as." Within the framework of this research, architectural design quality will be reviewed as the degree to which a design fulfils needs and expectations (Nelson, 2006) of stakeholders, which cannot be limited to only measurable/tangible/explicit criteria as defined by Deming (2000) within the classical quality management domain. It is believed that quality also has intangible criteria and aspects which should also be taken into account in its definition.

It is widely recognised that the most important measure in any evaluation of a building's design quality is whether it satisfies the stakeholders, mostly the users, and what they think and feel about it (Dickson, 2004). This is explicitly valid when multiple stakeholders have decision-making power 
within the process. However, understanding the views of the stakeholders is not easy (Dickson, 2004). Moreover the evaluation of stakeholders' ideas about the criteria, having tangible and intangible characteristics that require integration through the architectural design processes, is one of the major concerns in this respect.

Design quality assessment as a complex process is challenging since it has no solid definition. Although various definitions can be found, quality is a subjective matter based on perceived priorities (Choy and Burke, 2006). Since architectural design quality may be judged from different perspectives, it is hard to find systematic approaches. Regarding Simon's (1962) famous approach to coping with complexity, problems can be decomposed into semi-independent hierarchic components. Moving from this standpoint, for a proper approach for assessment of design quality, the formation of project-specific hierarchical criteria and sub-criteria may be considered to define exact limits, rather than searching for a methodology for a holistic assessment.

The definition of criteria for quality has been the key question and dates back to ancient times. Starting with Vitruvius throughout the history of architecture, the definition of criteria and sub-criteria has varied according to the era, technology, culture and the society (Harputlugil and Gültekin, 2009; Vitruvius, 1993), although his view is still, in essence, dominant in most approaches. In the contemporary world of designing, as the literature indicates, there are several approaches for criteria definition. Based on contemporary literature, architectural design quality in building environment can be grouped under three main titles: build quality, functionality and impact, which can be seen as a contemporary understanding of the Vitruvian principles. The key point of quality is that it can only be achieved when build quality, functionality and impact all work together (Simon, 1969; Gann et al, 2003; Volker, 2010; Harputlugil and Gültekin, 2009; Vitruvius, 1993; Cook, 2007; Prasad, 2004; Prins, 2009).

\section{RESEARCH METHODOLOGY}

\section{Purpose of the Research}

This article seeks to constitute an action research, defined as work in which the research actively and intentionally endeavours to effect a change in a (social) system (Coats, 2005). Its aim is to introduce an AHPbased approach (Figure 1). The approach seeks possible ways to translate/ transform stakeholders' ideas into decisions made in architectural design processes to improve architectural design quality. The conceptual framework of the approach was introduced by Harputlugil et al. (2011) (For an extensive report on the developed tool, see Harputlugil and Gültekin 2009, Harputlugil et al., 2011). The approach is more specifically developed for complex, multi-stakeholder environments in which stakeholders have decisive power. To this end, the usage of the developed AHP-based approach in the pre-design stage is implemented through a case study.

\section{Research Framework and Methodology}

The research implements an AHP-based approach through a case study for the pre-design stage. Outcomes of the case study will be used to further develop the tool as a structured design input mechanism and to enhance design quality during the design process. The research aims to 


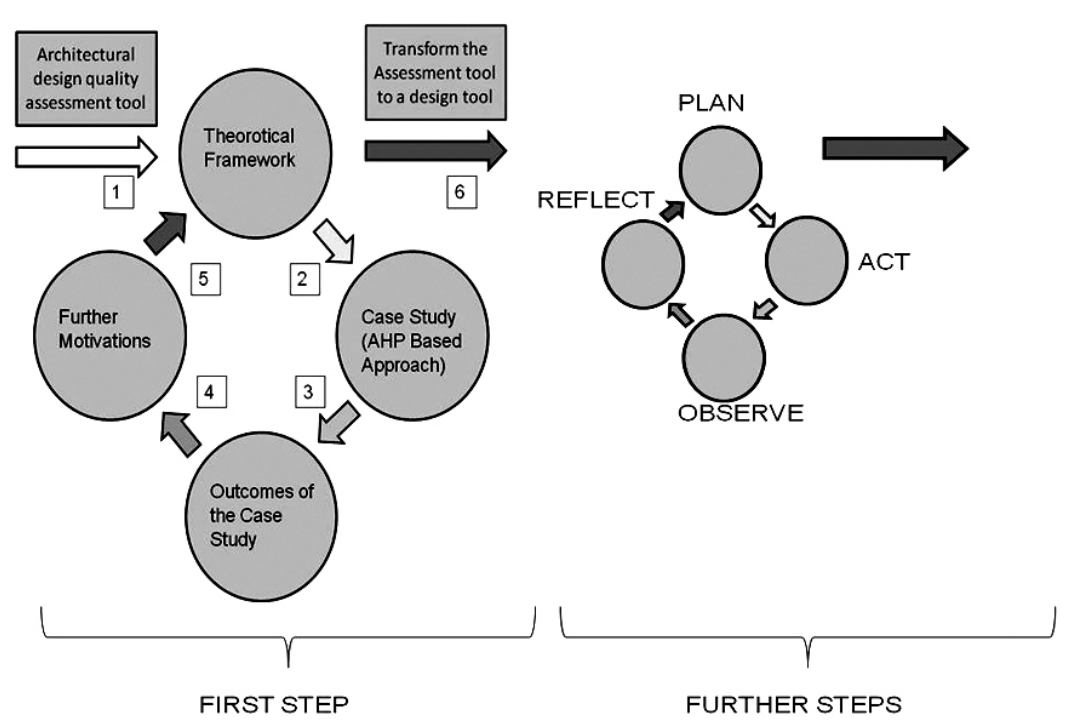

systematically reveal the potential of the AHP-based approach (assessment tool) to be transformed into a design tool (Figure 1).

\section{Research Questions}

This research aims to answer problems of the current practice related to design quality assessment through the questions specified as follows:

1) Does an AHP-based approach -a MCDM methodology- adequately assess architectural design quality for design makers and clients?

2) Can the AHP-based approach be useful for pre-design stages to get stakeholders' ideas/priorities for architectural design quality?

3) Does the approach help to improve architectural design quality?

4) Can the approach be transformed into a design tool?

\section{Work Flow of the Research}

The work flow of the AHP-based approach as tested within this research can be summarized in three steps. In the first step, the criteria of architectural design quality were formulated. Considering the building typology, criteria and sub-criteria for design quality assessment were introduced beforehand to the participants by the authors since it was the first time/test cycle that the approach was in use. Selected criteria and subcriteria were mainly derived from currently used tools (DQI, AEDET, HQI, LEED, BREAM, BQA), articles of Gann et al., (2003), Whyte et al., (2003) Harputlugil et al., (2011) and finally the experiences of the authors. The defined tangible and intangible criteria/sub-criteria for quality are classified hierarchically (Figure 2a).

The criteria used for the approach may be systematized based on four main principles/conditions:

1. partly generic using Vitruvian trilogy,

2. partly depending on societal circumstances,

3. partly specific depending on building type, and 
Figure 2a. $1^{\text {st }}$ Step of the methodology

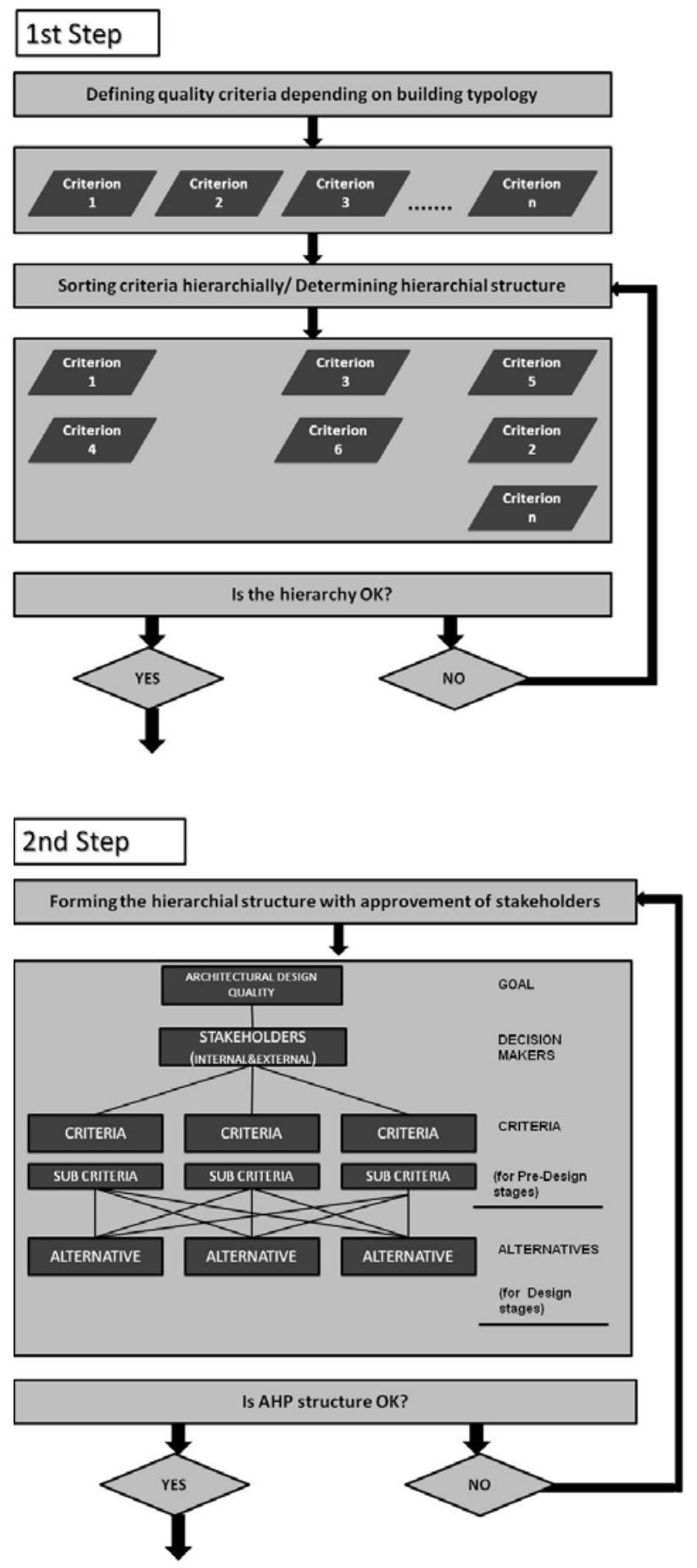

4. partly project specific depending on stakeholders' judgments and agreed preferences.

In the second step, an AHP structure is introduced. Related to the structure of AHP, architectural design quality in health care facilities is defined as the goal. Internal stakeholders with decisive power are determined and listed as decision makers. Criteria and sub-criteria were reviewed with decision makers (Figure 2b). Although an AHP-based approach can evaluate alternatives, no design alternatives were assessed since the aim of the case 


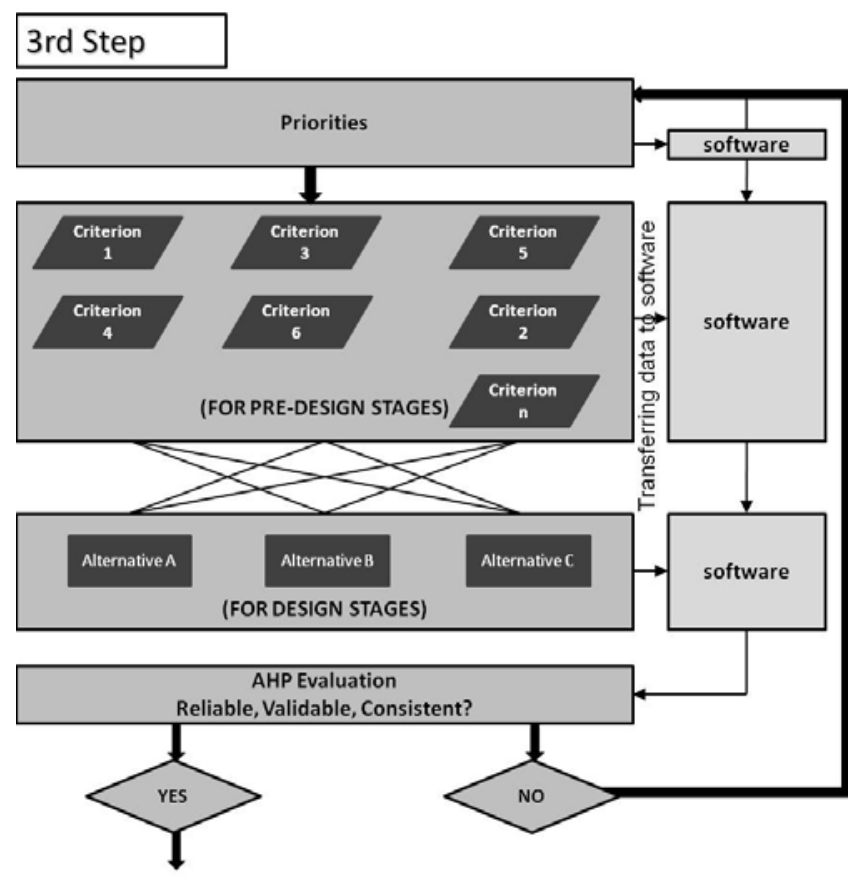

study was to bring out the priorities stakeholders identified as valid in the pre-design stage of the process.

In the third step, the preferences of the stakeholders for priorities for architectural design quality are evaluated through the AHP-based approach with the help of an academic version of a commercial AHP software (academic version of Expert Choice 11.5) package (Figure 2c). All surveys were conducted face to face to avoid any mistake in collecting the data. For the final step, outcomes are classified as individual, group and combined results. Outcomes of the AHP-based approach are reported as priorities of the stakeholders.

\section{Analytic Hierarchy Process (AHP)}

AHP, which can be used for individual and group decision processes, consists of three main operations: hierarchy construction, priority analysis and consistency verification (Ho, 2008). It accommodates a multi-level hierarchical structure of goal/objectives, decision makers, criteria/subcriteria, and alternatives (Triantaphyllou and Mann, 1995). Once the hierarchy has been constructed, AHP captures priorities from a set of pair-wise comparisons. Triantaphyllou and Mann $(1995,35)$ clarify these comparisons as "they are used to acquire the weights of importance of the decision criteria and the relative performance measures of the alternatives in terms of each individual decision criterion".

If the comparisons are not perfectly consistent, then the AHP method provides a mechanism for improving consistency. The wide applicability of AHP in different areas can be characterized by its simplicity, ease of use, and great flexibility (Saaty, 1980; 1990; Triantaphyllou and Mann, 1995; Hopfe, 2009; Ho, 2008; Harputlugil, 2012). 


\section{ANALYTIC HIERARCHY PROCESS (AHP) BASED APPROACH FOR ARCHITECTURAL DESIGN QUALITY ASSESSMENT}

\section{Concept of the Approach}

"Making comparisons is a talent we all have." (Hubka, 1992)

Cognitive Psychology has found that people are poor at processing large quantities of information on complex problems (Topçu, 1999). Miller (1956) indicates that the capacity of human short term memory is limited to seven separate items, plus or minus two. He stresses that the brain of a regular human can simultaneously process, differentiate, and deal with at most seven factors. For some people, this limit can be decreased to five, for others it can be increased to nine. Furthermore, Sweller et al. (1998) state in their article "Cognitive Architecture And Instructional Design" that

"Working memory is most commonly used to process information in the sense of organizing, contrasting, comparing, or working on that information in some manner, humans are probably only able to deal with two or three items of information simultaneously when required to process rather than merely hold information" (Sweller et al. 1998).

In the perspective of Simon (1962), complexity is characterised by a large number of parts that interact in a non-simple way. Judging the overall performance of a design is challenging considering its complexity (Zeleny, 1982). To cope with the complexity of the design process conceptually, a pair-wise compared, hierarchical multi-criteria decision-making model which can reveal priorities for the defined criteria is offered as a mode of assessment of architectural design quality. Pair-wise comparison is chosen in particular because of its ability to deal with intangible criteria and then relate them in a meaningful way to the tangibles that we know how to measure (Saaty, 2008).

As has been discussed, the Analytic Hierarchy Process (AHP) based on the assumption that complex decisions can be hierarchically structured is a multi-criteria decision-making (MCDM) approach and was introduced by Saaty (Saaty, 1980 and 1990; Triantaphyllou and Mann, 1995; Hopfe; 2009). The AHP is a decision support tool which can be used to solve complex decision problems, and has attracted the interest of many researchers for the fact that the required input data are relatively easy to obtain and for its ability to help capture both subjective and objective evaluation measures (Triantaphyllou and Mann, 1995).

\section{Framework of the Approach}

Assessment of architectural design quality is a complex problem. Rather than making a totalitarian statement for architectural design quality and make assessment based on that, this research offers to cope with this complexity by degrading the problem into its possible sub-systems, and assess sub-systems jointly or severally based on Simon's ideas. Simon believes that to cope with complexity, problems should be broken down to their hierarchical sub-systems. Hence, in this research, architectural design quality is degraded to hierarchical sub-systems defined as criteria and subcriteria. Stakeholders with decisive power in the early design process are asked to assess all these criteria and sub-criteria relatively.

The ideas and images of the design objects exist prior to and instead of the physical design objects in early design phases. The aim of this research is to reveal the ideas and images of stakeholders about architectural design quality in the pre-design stage. This aim can be identified with Plato's 
allegory of the cave. Referring to Plato, this research aims to clarify the fuzzy ideas of stakeholders and transform them into design knowledge about architectural design quality that can be used by the design team before the process begins. The aim is to reveal the priorities based on ideas and images of the stakeholders which can be defined and assessed numerically. This design knowledge about architectural design quality is essential since the decisions in early design stages have significant impacts on the final design product.

The framework of the approach is constructed to reveal the priorities of stakeholders based on hierarchically formed criteria and sub-criteria of architectural design quality which can be numerically analyzed before the early design stages. It is also aimed to create "what-if..." analysis scenarios considering integrated design teams, individual and groups decision making processes.

In the light of these concerns, probing the approach and methodology, Saaty (2008) states that in mathematics, there are two fundamentally different kinds of topology listed as metric and order:

\begin{abstract}
"The first is concerned with how much of a certain attribute an element has, as measured on a scale with an arbitrary unit and an origin that is applied uniformly to measure all objects with respect to the given property. The arbitrariness of the unit requires that one must use judgment by an expert to determine the meaning of the numerical outcomes with respect to observables and to compare them with what was comprehended before. .... The second kind of topology is concerned with measurement of the dominance of one element over others with respect to a common attribute. Order properties belong to the mental world with regard to the importance of its happenings according to human values, preferences and estimation of likelihoods, thereby always requiring judgment before the measurements are made, and not after, as with metric properties. The outcome of such numerical measurements is known as priorities" (Saaty, 2008).
\end{abstract}

Based on these ideas, understanding the priorities of stakeholders, rather than using conventional methods to assess architectural design quality through criteria covering intangible facts, the AHP-based assessment approach is introduced with pair-wised comparison of hierarchically listed criteria as a basis. The approach has been organised as based on the premises listed below:

1) It is obvious that decisions made during the design process influence architectural design quality. The proposed approach should assist in making reasoned choices based on stakeholder preferences and should cover the whole design process starting from pre-design to final design.

2) Architectural design differs from other branches of design with its content and context, and the complexity of both. Thus the evaluation cannot be limited only to design team actors. Other participants in the process, internal and external stakeholders, should be involved in the assessment process. The approach must establish an operating unit in which internal and external stakeholders can put forth their ideas/approvals for better integration. For this reason, the approach should be designed not only for professional design actors but also for the other non-expert stakeholders involved, especially those with decision-making power. Their effects on decisions may also need to be defined by weighing algorithms which might be demanded depending on the specific case. 
3) Consistency should be an important factor. Considering the complexity of transforming non-expert stakeholders' ideas into inputs for the design process by using paper work-related evaluations, may produce inconsistent outcomes. The proposed approach should deal with the measurement of inconsistency through evaluation for the purpose of obtaining consistent results.

4) Criteria for assessment of architectural design quality are defined in different ways in every era and society and might even be project specific. Thus an adaptable methodology should be designed for definition of criteria for different societies and projects instead of using a universal definition/criterion. Criteria selection should be reviewed on a project-specific level depending on stakeholders' judgments and agreed preferences. The proposed approach should be applicable to all building types, for different societies and should provide the possibility of adaptability.

5) As architectural design is intrinsically characterised by its tangible and intangible components, the approach should choose a methodology other than Likert Scaling to succeed in the evaluation of intangible criteria as well as of the tangibles. The approach may use pair-wise comparisons to judge the relative importance of the criteria with each other. By comparing, the preferred object can be not only indicated, but also discriminated among varying intensities of preferences ( Sweller et al. 1998; Harputlugil et al. 2011).

Based on these premises, AHP has been chosen as a methodology for the assessment of architectural design quality since it provides a comprehensive and rational framework for structuring a decision problem, for representing and quantifying its elements (tangibles, as well as intangibles), for relating those elements to the overall goals, and for evaluating alternative solutions.

\section{CASE STUDY}

Based on theoretic proposal, a case study was conducted to testify the approach. The case study aimed to reveal whether it is possible to bring out the consistent priorities of the stakeholders of a project for architectural design quality for early design stages and make them available information to the design team. Outcomes were not limited to obtaining numerical values, on the contrary generation of discernible design knowledge about architectural design quality was expected.

The developed approach was implemented in a case study in cooperation with one of the biggest health care providers of Turkey which has its own project management group for designing, building and operating its health care facilities. Their experience not only in health care but also in procurement processes in construction was one of the reasons for the cooperation. The health care sector was mainly chosen because of;

1) the building complexity considering its functions,

2) the number of decisive stakeholders for the design process,

3) the relative strong focus on user-oriented design, and

4) the often more systematic approach to design processes. 
Figure 3. AHP Hierarchy and Matrixes (Saaty, 1980; 1990)
Figure 4. Structure of the Approach Used for Case Study

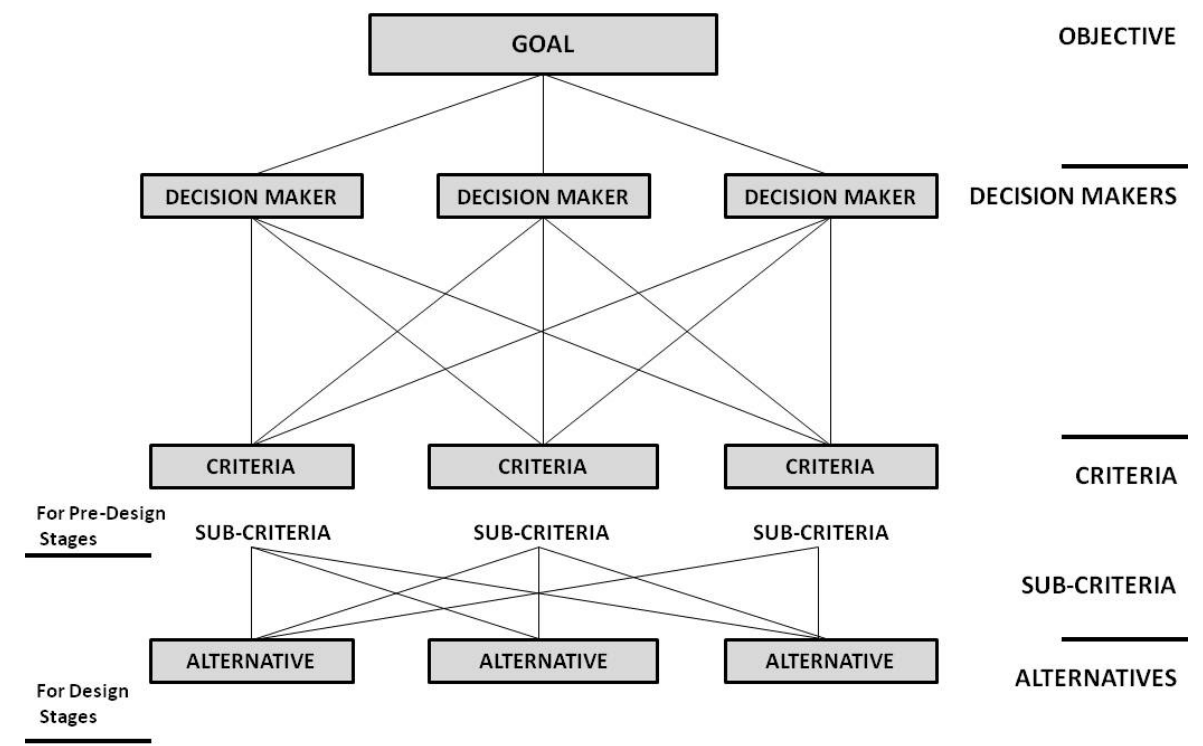

These characteristics of health care construction projects make them explicitly suitable to implement MCDM type quality assessment methodologies.

\section{Structure of the Approach}

The structure of the approach forms an explorative investigation into this field and analysis of current architectural design quality assessment tools. The tools were reviewed within the context of their methodology, aim of assessment, and evaluation. Depending on the literature review, 
architectural design quality is grouped under three main titles/criteria as "build quality", "functionality" and "impact" which can be seen as a modern-day interpretation of the Vitruvian framework .

For the proposed approach to explore the design quality of a building the three main titles listed above act as follows. Function encompasses aspects of its use, access and space. Build quality encompasses aspects of its performance, engineering systems and construction. And impact encompasses aspects of its contribution to form and materials, identity and character. This combination provides a hierarchical structure to be used as depicted in Figure 4 (Dickson, 2004; Cardellino et al., 2009; Harputlugil et al., 2011; Cook, 2007; Prins, 2009).

\section{Participants, Data Gathering and Analysis}

In terms of internal stakeholders, surveys were conducted not only with the Project Management Group (PMG), but also with various user profiles at an Istanbul hospital of the Health Group (HG) which was recently designed and constructed by its PMG. The PMG is responsible for investment planning, design, resource supplying, construction and operations, and consists of professionals from different domains of design and construction. Surveys were conducted with 29 participants, including both main decision makers on the design team and the users of the hospital, as well as randomly chosen patients. The design team consisted of architects, civil engineers, mechanical engineers, electrical engineers, consultants, and directors of the project management department. The users consisted of the hospital experienced administrative staff, doctors, nurses, and randomly chosen patients. Distribution of the participants is listed in Table 1.

All data related to design quality assessment with the described AHP tool is gathered through face to face surveys. Data are analysed with the help of commercial AHP software (academic version of Expert Choice 11.5). Human judgement dealing with intangible factors might suffer from inconsistency. To cope with inconsistency, an advantage of AHP is its provision of a mechanism/measure for consistency check. As $10 \%$ error is the suggested acceptable limit for inconsistency, special attention is exclusively paid to inconsistency levels through surveys.

Table 1. Distribution of the Participants

\begin{tabular}{|c|c|c|c|c|c|c|c|c|}
\hline \multirow{2}{*}{$\begin{array}{l}\text { Project } \\
\text { Management } \\
\text { (Design and } \\
\text { ProcurementTeams) }\end{array}$} & Architects & Electrical Eng. & $\begin{array}{l}\text { Mechanical } \\
\text { Eng. }\end{array}$ & Civil Eng. & $\begin{array}{l}\text { Building } \\
\text { Technician }\end{array}$ & $\begin{array}{l}\text { Tech. } \\
\text { Office } \\
\text { Staff }\end{array}$ & $\begin{array}{l}\text { Product } \\
\text { Director }\end{array}$ & Total \\
\hline & 5 & 1 & 2 & 1 & 1 & 1 & 1 & 13 \\
\hline \multirow[t]{2}{*}{$\begin{array}{l}\text { Client } \\
\text { (Consultant and } \\
\text { Project Team) }\end{array}$} & $\begin{array}{l}\text { Head of } \\
\text { the Project } \\
\text { management } \\
\text { Team }\end{array}$ & $\begin{array}{l}\text { Technical } \\
\text { Consultant }\end{array}$ & & & & & & \multirow[t]{2}{*}{2} \\
\hline & 1 & 1 & & & & & & \\
\hline \multirow[t]{2}{*}{ Users } & Doctors & Pharmacist & Nurses & $\begin{array}{l}\text { Technical } \\
\text { Director }\end{array}$ & $\begin{array}{l}\text { Bio- } \\
\text { Medical } \\
\text { Staff }\end{array}$ & Managers & Patient & \multirow[t]{2}{*}{14} \\
\hline & 3 & 1 & 2 & 1 & 1 & 2 & 4 & \\
\hline TOTAL & & & & & & & & 29 \\
\hline
\end{tabular}




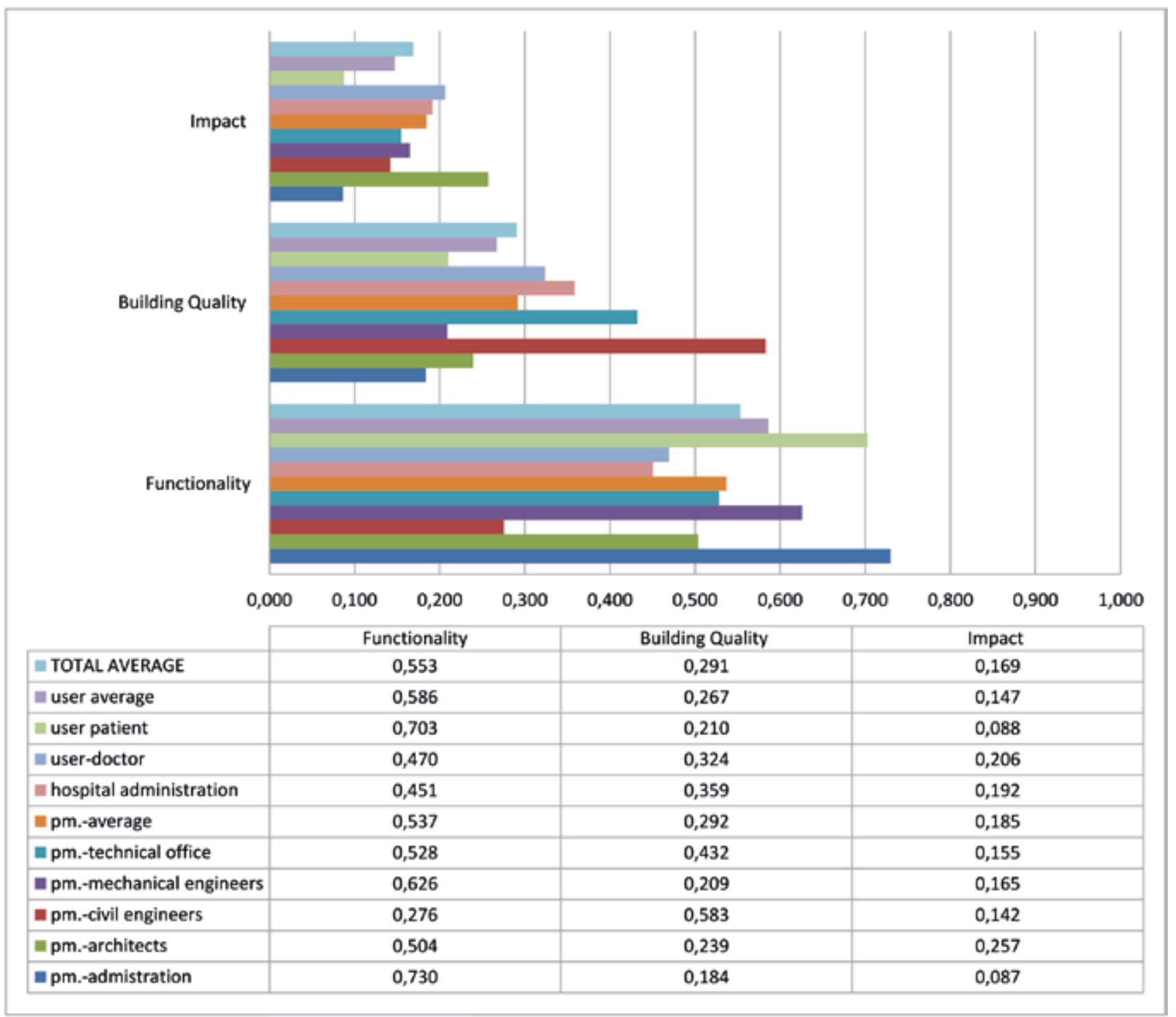

\section{Results of the Quality Assessment Done}

Distribution of the main criteria, namely functionality, build quality and impact, related to the participants is shown in Figure 5. Looking through general averages, all the other stakeholders who participated, except civil engineers, think that functionality is the major criterion followed by build quality and impact respectively. As for evaluation related to percentages, the administration of PMG defines functionality as the main criterion for quality, followed by the architects. Civil engineers tend to focus more on the build quality, while users-patients are relatively more concentrated on the impact compared to the other participants (Figure 5).

Distribution of sub criteria of functionality, build quality and impact, related to the participants is shown in Figure 3, 4, 5 respectively.

Space access and use were defined as the sub-criteria for functionality. The relative priority classification is listed as use, access and space. It is important to see whether the approach reflects the priorities of stakeholders and transform it into design knowledge for the design team. 


\begin{tabular}{|c|c|c|c|c|c|c|c|c|c|c|c|c|}
\hline & 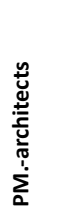 & 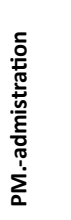 & 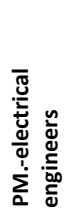 & 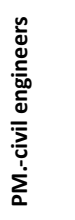 & 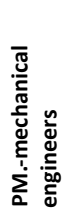 & 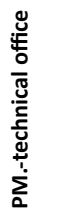 & 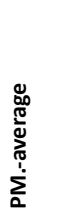 & 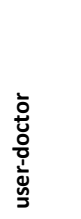 & 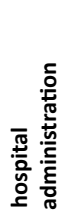 & 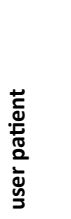 & 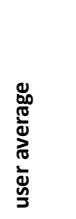 & 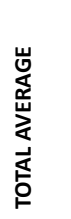 \\
\hline Functionality & 0.504 & 0.730 & 0.692 & 0.276 & 0.626 & 0.528 & 0.537 & 0.470 & 0.451 & 0.703 & 0.586 & 0.553 \\
\hline Space & 0.074 & 0.249 & 0.063 & 0.027 & 0.269 & 0.093 & 0.120 & 0.081 & 0.198 & 0.139 & 0.110 & 0.133 \\
\hline $\begin{array}{l}\text { Space size and } \\
\text { proportions }\end{array}$ & 0.008 & 0.063 & 0.012 & 0.001 & 0.036 & 0.006 & 0.018 & 0.003 & 0.013 & 0.044 & 0.023 & 0.021 \\
\hline Fit for purpose & 0.023 & 0.046 & 0.021 & 0.005 & 0.108 & 0.024 & 0.035 & 0.021 & 0.093 & 0.026 & 0.023 & 0.041 \\
\hline $\begin{array}{l}\text { Relation with } \\
\text { spaces }\end{array}$ & 0.012 & 0.042 & 0.010 & 0.008 & 0.035 & 0.019 & 0.019 & 0.021 & 0.026 & 0.016 & 0.019 & 0.021 \\
\hline Privacy & 0.004 & 0.024 & 0.003 & 0.003 & 0.028 & 0.008 & 0.010 & 0.008 & 0.026 & 0.026 & 0.017 & 0.014 \\
\hline Access & 0.012 & 0.046 & 0.009 & 0.008 & 0.032 & 0.020 & 0.020 & 0.017 & 0.023 & 0.015 & 0.016 & 0.020 \\
\hline Settlement & 0.015 & 0.029 & 0.007 & 0.005 & 0.031 & 0.017 & 0.017 & 0.012 & 0.018 & 0.012 & 0.012 & 0.016 \\
\hline Access & 0.176 & 0.172 & 0.315 & 0.059 & 0.090 & 0.224 & 0.167 & 0.146 & 0.114 & 0.367 & 0.256 & 0.185 \\
\hline Local access & 0.048 & 0.015 & 0.059 & 0.014 & 0.022 & 0.082 & 0.043 & 0.061 & 0.039 & 0.123 & 0.092 & 0.051 \\
\hline Interior access & 0.041 & 0.033 & 0.076 & 0.014 & 0.021 & 0.042 & 0.036 & 0.032 & 0.031 & 0.065 & 0.048 & 0.039 \\
\hline $\begin{array}{l}\text { Inter- floor } \\
\text { access }\end{array}$ & 0.039 & 0.033 & 0.076 & 0.008 & 0.010 & 0.045 & 0.034 & 0.023 & 0.020 & 0.051 & 0.037 & 0.034 \\
\hline $\begin{array}{l}\text { Inter-unit } \\
\text { access }\end{array}$ & 0.048 & 0.091 & 0.104 & 0.024 & 0.037 & 0.056 & 0.054 & 0.031 & 0.024 & 0.128 & 0.079 & 0.060 \\
\hline Use & 0.254 & 0.309 & 0.315 & 0.190 & 0.269 & 0.212 & 0.250 & 0.242 & 0.139 & 0.197 & 0.220 & 0.236 \\
\hline $\begin{array}{l}\text { Fit for } \\
\text { functionality }\end{array}$ & 0.129 & 0.079 & 0.189 & 0.106 & 0.132 & 0.080 & 0.114 & 0.104 & 0.040 & 0.084 & 0.094 & 0.105 \\
\hline Flexibility & 0.054 & 0.035 & 0.063 & 0.021 & 0.058 & 0.060 & 0.049 & 0.041 & 0.050 & 0.052 & 0.046 & 0.048 \\
\hline Adaptability & 0.070 & 0.196 & 0.063 & 0.063 & 0.079 & 0.072 & 0.087 & 0.097 & 0.050 & 0.062 & 0.080 & 0.083 \\
\hline
\end{tabular}

Table 2. Pre-Design Priorities for functionality
In this context, some important outcomes of the sub-criteria of functionality can be listed as follows:

- PM administration and user patients believe that functionality is more important than the other main criteria in architectural design quality, while civil engineers believe the opposite.

- Privacy in space is seen one of important issue for the patient rather than architects and PM administration

- User patients think that access is the most important sub-criterion of functionality

- PM administration give more importance to adaptability than flexibility.

Based on the distribution of priorities more detailed results including the sub-criteria can be found in Table 2.

Engineering systems, construction and performance were defined as the sub-criteria for build quality. The relative priority classification, depending on relative importance, is listed as performance, engineering systems and construction. In this context, some important outcomes of the sub-criterion of functionality can be listed as follows:

- Civil engineers and PM technical office believe that build quality is more important than the other main criteria in architectural design quality, while PM electrical engineers believe the opposite 


\begin{tabular}{|c|c|c|c|c|c|c|c|c|c|c|c|c|}
\hline & 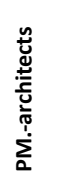 & 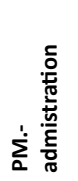 & 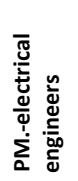 & 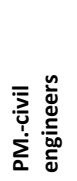 & 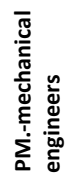 & 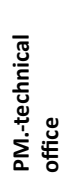 & 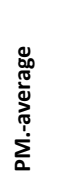 & 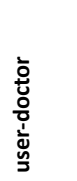 & 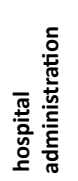 & 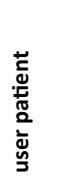 & 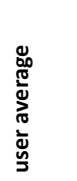 & 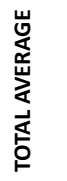 \\
\hline Building Quality & 0.239 & 0.184 & 0.077 & 0.583 & 0.209 & 0.432 & 0.292 & 0.324 & 0.359 & 0.210 & 0.267 & 0.291 \\
\hline $\begin{array}{l}\text { Engineering } \\
\text { Systems }\end{array}$ & 0.081 & 0.085 & 0.046 & 0.134 & 0.085 & 0.109 & 0.092 & 0.144 & 0.123 & 0.125 & 0.134 & 0.103 \\
\hline Lighting & 0.007 & 0.010 & 0.006 & 0.015 & 0.003 & 0.008 & 0.008 & 0.013 & 0.010 & 0.006 & 0.009 & 0.009 \\
\hline Natural & 0.005 & 0.009 & 0.004 & 0.012 & 0.002 & 0.005 & 0.006 & 0.010 & 0.004 & 0.003 & 0.007 & 0.006 \\
\hline Artificial & 0.002 & 0.002 & 0.002 & 0.003 & 0.001 & 0.003 & 0.002 & 0.003 & 0.007 & 0.003 & 0.003 & 0.003 \\
\hline Ventilation & 0.010 & 0.017 & 0.012 & 0.017 & 0.019 & 0.015 & 0.014 & 0.017 & 0.014 & 0.011 & 0.014 & 0.015 \\
\hline Natural & 0.003 & 0.002 & 0.006 & 0.007 & 0.003 & 0.003 & 0.004 & 0.007 & 0.008 & 0.008 & 0.007 & 0.005 \\
\hline Artificial & 0.009 & 0.015 & 0.006 & 0.011 & 0.016 & 0.012 & 0.011 & 0.010 & 0.006 & 0.003 & 0.006 & 0.010 \\
\hline Air conditioning & 0.012 & 0.013 & 0.040 & 0.016 & 0.015 & 0.010 & 0.014 & 0.013 & 0.016 & 0.016 & 0.014 & 0.017 \\
\hline Sterilization & 0.015 & 0.018 & 0.007 & 0.042 & 0.021 & 0.044 & 0.025 & 0.025 & 0.023 & 0.029 & 0.027 & 0.025 \\
\hline $\begin{array}{l}\text { Electrical } \\
\text { systems- } \\
\text { Automation }\end{array}$ & 0.017 & 0.007 & 0.008 & 0.022 & 0.008 & 0.013 & 0.014 & 0.020 & 0.016 & 0.016 & 0.018 & 0.014 \\
\hline Security & 0.015 & 0.005 & 0.008 & 0.016 & 0.015 & 0.013 & 0.013 & 0.039 & 0.037 & 0.036 & 0.037 & 0.020 \\
\hline $\begin{array}{l}\text { Acoustic (Noise } \\
\text { control) }\end{array}$ & 0.005 & 0.017 & 0.002 & 0.007 & 0.004 & 0.006 & 0.007 & 0.017 & 0.008 & 0.012 & 0.015 & 0.009 \\
\hline Construction & 0.078 & 0.037 & 0.015 & 0.353 & 0.033 & 0.072 & 0.098 & 0.046 & 0.113 & 0.025 & 0.035 & 0.086 \\
\hline Durability & 0.011 & 0.017 & 0.003 & 0.048 & 0.009 & 0.025 & 0.019 & 0.008 & 0.026 & 0.008 & 0.008 & 0.017 \\
\hline Detail Solutions & 0.014 & 0.003 & 0.030 & 0.019 & 0.008 & 0.007 & 0.012 & 0.007 & 0.017 & 0.002 & 0.004 & 0.012 \\
\hline $\begin{array}{l}\text { Code } \\
\text { compliance }\end{array}$ & 0.008 & 0.010 & 0.001 & 0.083 & 0.005 & 0.016 & 0.019 & 0.010 & 0.017 & 0.005 & 0.007 & 0.017 \\
\hline $\begin{array}{l}\text { Structural } \\
\text { design }\end{array}$ & 0.016 & 0.003 & 0.002 & 0.091 & 0.004 & 0.009 & 0.020 & 0.009 & 0.017 & 0.003 & 0.006 & 0.017 \\
\hline Finishings & 0.015 & 0.003 & 0.002 & 0.032 & 0.003 & 0.007 & 0.012 & 0.008 & 0.018 & 0.002 & 0.005 & 0.010 \\
\hline $\begin{array}{l}\text { Structural } \\
\text { material } \\
\text { selection }\end{array}$ & 0.013 & 0.002 & 0.003 & 0.080 & 0.006 & 0.007 & 0.018 & 0.006 & 0.018 & 0.005 & 0.006 & 0.016 \\
\hline Performance & 0.080 & 0.062 & 0.015 & 0.097 & 0.091 & 0.136 & 0.088 & 0.135 & 0.123 & 0.061 & 0.098 & 0.089 \\
\hline $\begin{array}{l}\text { Occupancy } \\
\text { Performance }\end{array}$ & 0.025 & 0.034 & 0.003 & 0.026 & 0.025 & 0.045 & 0.029 & 0.025 & 0.022 & 0.023 & 0.024 & 0.025 \\
\hline $\begin{array}{l}\text { Energy } \\
\text { Performance }\end{array}$ & 0.020 & 0.010 & 0.009 & 0.051 & 0.054 & 0.046 & 0.032 & 0.026 & 0.047 & 0.008 & 0.017 & 0.030 \\
\hline $\begin{array}{l}\text { Functional } \\
\text { Performance }\end{array}$ & 0.035 & 0.018 & 0.003 & 0.021 & 0.013 & 0.044 & 0.028 & 0.085 & 0.025 & 0.031 & 0.058 & 0.031 \\
\hline
\end{tabular}

Table 3. Pre-Design Priorities for Build Quality
- User doctor, user patient and PM administration consider acoustics (noise control) more than architects

- User patients give more credits to performance, sterilization, security and air conditioning than any other sub-criteria

Based on the distribution of priorities, detailed results including the subcriteria can be found in Table 3 .

Form and Materials, Identity and Character were defined as the sub-criteria for impact. In terms of relative importance the priority classification is listed as character, identity and form and materials. In this context, some important outcomes of the sub-criterion of functionality can be listed as follows:

- PM administration and user patient believe that impact is the least important criteria for architectural design quality 


\begin{tabular}{|c|c|c|c|c|c|c|c|c|c|c|c|c|}
\hline & 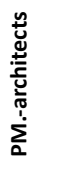 & 这 & 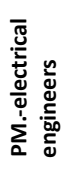 & 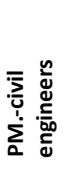 & 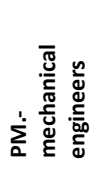 & 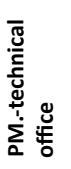 & 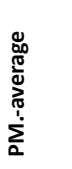 & 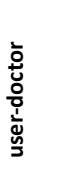 & 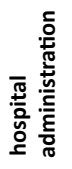 & 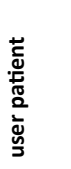 & 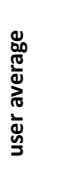 & 占岕 \\
\hline Impact & 0.257 & 0.087 & 0.231 & 0.142 & 0.165 & 0.155 & 0.185 & 0.206 & 0.192 & 0.088 & 0.147 & 0.169 \\
\hline $\begin{array}{l}\text { Form and } \\
\text { Materials }\end{array}$ & 0.037 & 0.029 & 0.138 & 0.010 & 0.074 & 0.030 & 0.042 & 0.040 & 0.084 & 0.043 & 0.042 & 0.054 \\
\hline $\begin{array}{l}\text { Colour and } \\
\text { texture }\end{array}$ & 0.007 & 0.012 & 0.039 & 0.003 & 0.019 & 0.007 & 0.011 & 0.021 & 0.042 & 0.008 & 0.014 & 0.017 \\
\hline Form & 0.023 & 0.008 & 0.019 & 0.004 & 0.019 & 0.010 & 0.015 & 0.011 & 0.013 & 0.007 & 0.009 & 0.013 \\
\hline Traditional & 0.003 & 0.002 & 0.005 & 0.002 & 0.005 & 0.002 & 0.003 & 0.002 & 0.003 & 0.002 & 0.002 & 0.003 \\
\hline Contemporary & 0.021 & 0.006 & 0.014 & 0.003 & 0.014 & 0.008 & 0.012 & 0.009 & 0.010 & 0.006 & 0.008 & 0.010 \\
\hline Material & 0.007 & 0.010 & 0.081 & 0.004 & 0.036 & 0.014 & 0.017 & 0.008 & 0.028 & 0.028 & 0.018 & 0.024 \\
\hline Traditional & 0.001 & 0.003 & 0.020 & 0.001 & 0.009 & 0.004 & 0.004 & 0.002 & 0.005 & 0.005 & 0.003 & 0.005 \\
\hline Contemporary & 0.005 & 0.008 & 0.061 & 0.003 & 0.028 & 0.009 & 0.013 & 0.006 & 0.023 & 0.023 & 0.014 & 0.018 \\
\hline Identity & 0.064 & 0.027 & 0.046 & 0.100 & 0.029 & 0.062 & 0.058 & 0.088 & 0.035 & 0.016 & 0.052 & 0.052 \\
\hline Age & 0.021 & 0.003 & 0.013 & 0.007 & 0.007 & 0.009 & 0.012 & 0.018 & 0.010 & 0.002 & 0.010 & 0.010 \\
\hline Movement & 0.012 & 0.007 & 0.006 & 0.018 & 0.005 & 0.018 & 0.012 & 0.025 & 0.012 & 0.006 & 0.016 & 0.012 \\
\hline Order & 0.031 & 0.017 & 0.027 & 0.074 & 0.018 & 0.035 & 0.033 & 0.045 & 0.013 & 0.008 & 0.027 & 0.030 \\
\hline Character & 0.156 & 0.032 & 0.046 & 0.034 & 0.063 & 0.062 & 0.085 & 0.079 & 0.074 & 0.028 & 0.053 & 0.064 \\
\hline Aesthetics & 0.019 & 0.006 & 0.027 & 0.010 & 0.019 & 0.010 & 0.015 & 0.018 & 0.024 & 0.010 & 0.014 & 0.016 \\
\hline Context & 0.030 & 0.009 & 0.006 & 0.019 & 0.026 & 0.026 & 0.023 & 0.031 & 0.016 & 0.008 & 0.020 & 0.019 \\
\hline Image & 0.107 & 0.017 & 0.013 & 0.005 & 0.019 & 0.026 & 0.047 & 0.030 & 0.034 & 0.010 & 0.020 & 0.029 \\
\hline
\end{tabular}

Table 4. Pre-Design Priorities for Impact
- Among all participant groups architects give the most credit to impact

- All participants agree on using contemporary form and materials rather than traditional ones

- User doctors care for the identity of a building more than architects

- The identity of a building is the most important sub-criteria among others for the user groups average

- User and PM on average have more or less the same priorities about sub-criteria

- Hospital administration takes into account colour and form more than any other participants.

Based on the distribution of priorities, detailed results including the subcriteria can be found in Table 4 .

\section{OUTCOMES/DISCUSSIONS}

Architectural design quality is hard to evaluate due to its complexity. To cope with complexity, several systems and implementations are applied. To contribute to this range of research, an AHP based approach which covers the content of this paper is implemented through a case study. It aims to provide a more thorough analysis of the potentials of the approach for the early design stages. The main objective of this research is to seek the possibilities to generate design knowledge based on design quality from measurable and testable consistent data provided by the stakeholders. Considering the purposes listed above, a case study aiming to establish the theoretical proposal of the approach is conducted with a broad range of participants who have decisive power in the design processes. 
As the approach seeks possible ways to translate/transform stakeholders' ideas for decisions made during the architectural design processes to improve architectural design quality, the case study aims:

1) to reveal consistent priorities of the stakeholders of a project for architectural design quality for the early design stages and make the available information to the design team

2) to transform stakeholders' ideas into design knowledge for design teams

4) to get scientifically consistent data including from non-professional stakeholder sources as a means to contribute to better design knowledge

5) to find out whether it is possible to compare priorities of stakeholders based on tangible and intangible criteria

6) to check whether it is possible to create "what-if" scenarios for integrated design teams for better group decision making.

Through the case study, stakeholders' priorities related to design quality are revealed by using an AHP-based approach. Unlike the other conventional methods, AHP allows researchers to obtain consistent data from surveys of a limited range of participants with the most decisive power.

Following achievement of computing results of surveys with a software (expert choice 11.5 academic version), individual and group results are analysed. The outcomes were presented to head of design and the project management group with interviews conducted. Individual and group priorities leading to their design decisions were analyzed in depth, outcomes were discussed through the interviews with graphs covering "what-if" analysis scenario information. Following the discussion session a second survey to verify the reliability of the outcomes of the research was submitted only to the two top managers of the Project Management Group, the main decision makers. With only one response, outcomes from this survey (Grading 1/worst to 10/best) are listed in Table 5.

\begin{tabular}{|l|l|l|}
\hline Questions & \multicolumn{1}{|c|}{} & Grade \\
\hline $\mathbf{1}$ & $\begin{array}{l}\text { Do the survey results reflect your personal priorities/ } \\
\text { ideas? }\end{array}$ & $\mathbf{9}$ \\
\hline $\mathbf{2}$ & $\begin{array}{l}\text { Do you think that the results of group evaluation is } \\
\text { understandable? }\end{array}$ & $\mathbf{9}$ \\
\hline $\mathbf{3}$ & Do you think that individual outcomes are reliable ? & $\mathbf{8}$ \\
\hline $\mathbf{4}$ & Do you think that group outcomes are reliable ? & $\mathbf{7}$ \\
\hline $\mathbf{5}$ & $\begin{array}{l}\text { Do you think that your priorities are represented in } \\
\text { group decisions? }\end{array}$ & $\mathbf{8}$ \\
\hline $\mathbf{6}$ & $\begin{array}{l}\text { Do you think that AHP based approach can be applied in } \\
\text { pre design process. }\end{array}$ & $\mathbf{9}$ \\
\hline $\mathbf{7}$ & $\begin{array}{l}\text { Do you think that AHP based approach can be adapted } \\
\text { to be used in design process? }\end{array}$ & $\mathbf{9}$ \\
\hline $\mathbf{8}$ & $\begin{array}{l}\text { Do you offer others to use AHP based approach for } \\
\text { architectural design quality assessment tool for pre } \\
\text { design processes. }\end{array}$ & $\mathbf{8}$ \\
\hline
\end{tabular}


The main aim of this article is not only to discuss the data gathered via numeric survey results as listed above, but also to discuss the applicability of the AHP approach and its development as a design tool. Regarding these challenges, outcomes of the case study including interviews conducted with each participant after the survey, interviews conducted after survey analysis with design and PM team, personal observations and survey outcomes are listed below:

1) The proposed methodology enables stakeholders to contribute their ideas/preferences/priorities about architectural design quality at the pre-design phase. The application of the approach is easy to follow and the illustration of the results is easy, clear and comprehensible.

2) By using the approach, it is possible to get rapid and reliable results of the priorities and preferences of the stakeholders for the predesign processes.

3) It is possible to create "what-if" scenarios for further group decision making.

4) Consistency can be measured through an evaluation process. Inconsistent answers can be avoided.

5) Tangible/intangible and subjective/objective components of design can be assessed by using pair-wise comparisons in order to define priorities.

6) By means of this approach and through the use of the software (expert choice 11.5 academic version), weighting factors for each stakeholder can also be defined if the intention is to seek consensus decision-making.

7) Considering the feedback from non-professional stakeholders, some of the sub-criteria should be revised for better understanding.

8) Considering the feedback from the design team, outcomes of the table should be reported based on each criteria and sub-criteria based on "what-if" scenarios.

9) The approach must not be limited to its assessment methodology only, since it has potentials to be transformed into a design tool to evaluate alternatives due to design quality.

Actors of the design team found the approach useful to understand the occupants' choices based on relatively compared criteria to create more scenarios to update the design. On the other hand, occupants who are not professionals in the design and construction sectors found the approach as a translator of their expectations from the design, which they had struggled to express in the right terms. Moreover the PM administration found the approach an easy, simple and clear way to understand the priorities of occupants, the design team and other stakeholders. They believe the approach will be a constructive method to manage the process to develop quality within the design process.

As the approach seeks ways to realise stakeholders ideas about design quality in early design stages based on their priorities of criterion, depending on the outcomes of the case study, it may be stated that AHP based approach has substantial potential to be developed as a design tool for assessment of design quality for early design stages. 


\section{FUTURE WORK}

The approach based on AHP for assessment of architectural design quality was introduced into design stages through its use in the pre-design process, implemented with a case study. For future work, the aim is to use the approach for preliminary and other phases of design and also to test opportunities in terms of assessment of design alternatives. Moreover, the crucial step for developing the approach as a design tool will be successfully transferring assessment data into design input for design teams during the design stages. Therefore, developing the approach for other stages of design on its route to becoming a design tool depends on case studies specifically focusing on design teams.

\section{ACKNOWLEDGEMENTS}

This article includes one part of Timuçin Harputlugil's PhD thesis and his six months study at Delft University of Technology which was funded by The Scientific and Technological Research Council of Turkey (TÜBİTAK).

The authors would like to thank Ms. Aygün Kulaksız Yücel, Mr. A.Temel Baltaoğlu and Mr. Sedat Artukoğlu, on behalf of Project Management and Health Group, for their enormous support throughout the research.

\section{BIBLIOGRAPHY}

CARDELLINO, P., LEIRINGER, R., CLEMENTS-CROOME, D. (2009) Exploring the role of design quality in the building schools for the future programme, Architectural Engineering and Design Management 5(4) 249-62.

CHAN, C.S. (1990) Cognitive Processes in Architectural Design Problem Solving, Design Studies 11(2) 60-80.

CHOY, R., BURKE, N. (2006) Quality Specifications For Clients, Clients Driving Innovation: Moving Ideas into Practice, Cooperative Research Centre (CRC) for Construction Innovation.

COATS, M. (2005) Action Research: A Guide for Associate Lecturers, The Open University; 5-9.

COOK, M. (2007) The Design Quality Manual: Improving Building Performance, Wiley-Blackwell, Oxford; 1-57.

CORNICK, T. (1991) Quality Management For Building Design, ButterworthHeinemann Ltd.; 1-25.

DAHL, P. (2008) Managing End-User Feedback In Sustainable Project Delivery, Phd Thesis, The Pennsylvania State University, The Graduate School, Department of Architectural Engineering; 38-43,

DEMING, W.E. (2000) Out of the Crisis, MIT Press Edition, Massachusettes.

DICKSON, M. (2004) Achieving Quality In Building Design By Intention, Building Better Buildings, Spon Press, London; 185-94.

DQI, (2009) www.dqi.org.uk (last accessed April 2009).

FELLOWS, R., LIU, A. (2008) Research Methods For Construction, 3rd ed., Blackwell; 53-183.

GANN, D.M., SALTER A.J., WHYTE J.K. (2003) Design quality indicator as a tool for thinking, Building Research and Information 31(5) 318-33. 
GIDDINGS, B., SHARMA, M., JONES, P., JONES, M. (2010) Architectural design quality in local authority private finance initiative projects, W096 - Special Track 18th CIB World Building Congress, Salford; 23-35.

HARPUTLUGIL, G.U., HENSEN J.L.M., ÇELEBİ, G. (2011) A prospect to develop thermally robust outline design and to explore its applicability to the different climate necessities of Turkey, International Journal of Low-Carbon Technologies 6(1) 76-85.

HARPUTLUGİL, T. (2012) Yapı Elde Etme Sürecinde Mimari Tasarım Kalitesinin Ölçülmesi ve Arttırllmasına Yönelik Analitik Hiyerarşi Prosesi Tabanlı Karar Destek Yaklaşımı ve Örnek Olaylarla Sınanması, yayınlanmamış Doktora Tezi, Gazi Universitesi, Fen Bilimleri Enstitüsü.

HARPUTLUGIL, T., GÜLTEKİN A. T. (2009) A conceptual framework to assess architectural design quality by analytic hierarchy process (AHP) and its integration to building contracts, Fifth International Conference on Construction in the 21st Century (CITC-V) Collaboration and Integration in Engineering, Management and Technology, İstanbul; 267-74.

HARPUTLUGIL, T., GÜLTEKİN, A.T., TOPÇU, İ. (2009) Architectural design quality: the practitioners' perspective - an AHP based approach for assessment, Changing Roles Conference, The Netherlands; 259-68.

HARPUTLUGIL, T., PRINS, M., GÜLTEKIN, A.T., TOPÇU, İ. (2011) Conceptual framework for potential implementations of multi criteria decision making (MCDM) methods for design quality assessment, MISBE Conference, Amsterdam, ISBN:9789052693958.

HO, W. (2008), Integrated analytic hierarchy process and its applications - a literature review, European Journal of Operational Research 186(1) 211-28.

HOPFE, C. (2009) Uncertainty and sensitivity analysis in building performance simulation for decision support and design optimization, $\mathrm{PhD}$ Thesis, Eindhoven University of Technology, The Netherlands.

HUBKA, V. (1992) Design for Quality and design methodology, Journal of Engineering Design 3(1) 5-15.

LAWSON B. (2005) How Designers Think, 4th edition, Elsevier, Oxford; 1203.

MILLER, A.G. (1956) The Magical Number Seven, Plus or Minus Two: Some Limits on Our Capacity for Processing Information, The Psychological Review (63) 81-97.

NELSON, C. (2006) Managing Quality in Architecture, Elsevier Pub., Oxford; 4-8.

ÖZCAN, T., ÇELEBI, N., ESNAF, Ş. (2011) Comparative analysis of multi-criteria decision making methodologies and implementation of a warehouse location selection problem, Expert Systems with Applications 38(8) 9773-9.

PRASAD, S. (2004) Inclusive Maps, Macmillan, S. ed., Designing Better Buildings, Spon Press, London; 175-84. 
PRINS, M. (2009) Architectural Value, Architectural Management:

International Research and Practice, eds. S. Emmitt, M. Prins and A. den Otter, Wiley-Blackwell, Oxford; 3-16 .

SAATY, T.L. (1980) The Analytic Hierarchy Process: Planning, Priority Setting, Resource Allocation, McGraw-Hill International, New York; 1-287.

SAATY, T.L. (1990) The Analytic Hierarchy Process For Decisions In A Complex World, RWS Publications, Pittsburgh.

SAATY, T.L. (2008) Relative measurement and its generalization in decision making why pairwise comparisons are central in mathematics for the measurement of intangible factors the analytic hierarchy/network process, Revista de la Real Academia de Ciencias Exactas, Fisicasy Naturales. Serie A. Matematicas 102(2) 251-318.

SIMON, H.A. (1969) The Sciences of the Artificial, M.I.T. Press, Cambridge; 55-118.

SIMON, H. (1962) The Architecture of Complexity, The American Philosophical Society 106(6) 467-82.

SWELLER, J., VAN MERRIENBOER J.J.G, PAAS, F.G.W.C. (1998) Cognitive Architecture and Instructional Design, Educational Psychology Review (10)3.

TOPÇU, Y.İ. (1999) Çok ölçütlü sorun çz̈zümüne yönelik bir bütünleşik karar destek modeli, yayınlanmamış Doktora Tezi, İstanbul Teknik Üniversitesi, Fen Bilimleri Enstitüsü.

TRIANTAPHYLLOU, E., MANN, S.H. (1995) Using The Analytic Hierarchy Process For Decision Making In Engineering Applications: Some Challenges, International Journal of Industrial Engineering: Applications and Practices 2(1) 35-44.

VAN AKEN, J.E. (2003) On The Design of Design Processes in Architecture And Engineering: Technological Rules And The Principle Of Minimal Specification, Eindhoven Centre for Innovation Studies, The Netherlands, Working Paper 03.08,1-3.

VISCHER, F. (2001) Learning From Our Buildings, A State of the Practice Summary of Post Occupancy Evaluation, Federal Facilities Council Technical Report (145), National Academy Press, Washington; 23-34 .

VITRUVIUS, M. (1993) Mimarlık Üzerine On Kitap, çev: Suna Güven, Şevki Vanlı Mimarlık Vakfı Yayınları, Ankara; 3-21.

VOLKER, L. (2010) Deciding About Design Quality, Unpublished Ph.D. Thesis, Delft University of Technology, Delft; 15-39.

WHYTE, J., GANN, D., SALTER, A. (2004) Building Indicators of Design Quality, Macmillan, S. ed., Designing Better Buildings, Spon Press; 195-205.

ZELENY, M. (1982) Multiple Criteria Decision Making, McGraw Hill; 85-94. 
Alındı: 01.12.2012; Son Metin: 02.11.2014

Anahtar Sözcükler: Analitik Hiyerarşi Süreci (AHS); mimari tasarım kalitesi; Çok Ölçütlü Karar Verme (ÇÖKV).

\section{MIMMARİ TASARIM KALITTESININN ANALITTIK HIYYERARŞİ SÜRECINNE DAYALI OLARAK DEĞERLENDİRILMESİ: BİR ÖRNEK OLAY ÇALIŞMASI}

Karmaşıklığından dolayı, mimari tasarım kalitesinin değerlendirilmesi zordur. Ölçütlerin belirlenmesi, yöntemin ortaya konması ve kalitenin kimin için, kimler tarafından ve nasıl değerlendirileceği mimarlık alanında süregelen önemli tartışma konularından biridir. Bu amaçla, devam eden tasarım süreçlerine girdi veremeyen, çoğunluğu kullanım süreci değerlendirmesinde kullanılan pek çok değerlendirme aracı geliştirilmiştir.

Bu yazı, tasarımın ilk aşamalarından son aşamalarına kadar kullanılabilecek Analitik Hiyerarşi Süreci (AHS) tabanlı yeni bir yöntem önermeyi amaçlamaktadır. Çok Ölçütlü Karar Verme (ÇÖKV), bireysel ve grup kararlarında soyut ve somut etkenlerin birlikte değerlendirilebildiği güçlü ve anlaşılabilir bir sistemdir. Bir ÇÖKV yöntemi olan AHP karar sorunlarını oluşturduğu hiyerarşik yapı ile tanımlar. Kalite göreli olarak değerlendirilebileceğinden, AHP tabanlı yaklaşım yapı elde etme sürecinin paydaşları gözünden süreç içerisindeki tercihlerini anlamayı amaçlamaktadır. Önerilen yaklaşım, Türkiye'nin önde gelen sağlık kuruluşlarının birinde örnek olay çalışması ile sınanmıştır.

\section{TIMUÇIN HARPUTLUGIL}

Assistant Professor in Çankaya University. Received his Bachelor, Master and Ph.D. degrees from the Department of Architecture at Gazi University. He was a guest researcher in Delft University of Technology for six months for his PhD studies granted by TUBITAK. His research areas are design quality and decision making process through design stages. tharputlugil@cankaya.edu.tr

\section{A.TANJU GÜLTEKİN}

Professor at Atılım University, specialized in project management. Headed for Departments of Architecture of Lefke and Çankaya Universities respectively. He has experience in construction sector as a construction manager. tanju.gultekin@atilim.edu.tr

\section{MATTHIJS PRINS}

Matthijs Prins is an Associate Professor in Design and Construction Management at the Department of Real Estate and Housing (RE\&H), Faculty of Architecture of Delft University of Technology, and is also director of Msc education of RE\&H. Completed his PhD studies at Eindhoven University of Technology in 1992. His research interests include architectural design management, construction management, decision support systems, BIM and integrated design and delivery systems. Matthijs is coordinator of the CIB working commission W096 on Architectural Management. M.Prins@tudelft.nl

\section{Y. İLKER TOPÇU}

İlker Topçu is a professor of Decision Sciences in the Industrial Engineering Department of Istanbul Technical University. Completed his Ph.D. study in 2000 at İstanbul Technical University and visited Leeds University Business School during these studies (1998-1999). Research interests include multiple criteria decision making, decision analysis, operations research/management science. ilker.topcu@itu.edu.tr 
